\author{
ks. Jacek Bramorski \\ Akademia Muzyczna w Cidańsku \\ Wydziat Dyrygentury Chóralnej, Muzyki Kościelnej, Edukacji Artystycznej, \\ Rytmiki i Jazzu \\ Katedra Muzyki Kościelnej
}

\title{
Muzyka sakralna jako vic pulchritudinis wyzwaniem dla kompozytorów
}

Kategoria via pulchritudinis, czyli „drogi piękna”, jest jednym z podstawowych paradygmatów pontyfikatu Benedykta XVI. Piękno wiary chrześcijańskiej stało się również przewodnim motywem obradującego w 2012 r. Synodu Biskupów, który poświęcony był nowej ewangelizacji. Jego uczestnicy wzywali do głoszenia Dobrej Nowiny za pośrednictwem via pulchritudinis. Otwiera to nową przestrzeń współpracy duszpasterzy i artystów, a w szczególny sposób teologów i kompozytorów złączonych troską o to, aby piękno wiary na nowo zajaśniało w świętej liturgii, której integralną częścią jest „muzyka na miarę świętości” ${ }^{1}$.

Myśl tę podjął papież Franciszek w posynodalnej adhortacji Evangelii gaudium, stwierdzając:

Dobrze by było, aby wszelka katecheza zwracała szczególną uwagę na „drogę piękna” (via pulchritudinis). [...] Wszystkie formy autentycznego piękna mogą być uznane za drogę prowadzącą do spotkania z Panem Jezusem. Nie chodzi o szerzenie relatywizmu estetycznego, który może zaciemnić nierozdzielny związek między prawdą, dobrem i pięknem, ale o przywrócenie szacunku dla piękna, by móc dotrzeć do ludzkiego serca i by w nim zajaśniała prawda oraz dobroć Zmartwychwstałego. Jeśli, jak twierdzi św. Augustyn, kochamy tylko to, co jest piękne, Syn, który stał się człowiekiem, objawieniem nieskończonego piękna, jest w najwyższym stopniu godny miłości i pociąga nas ku sobie więzią miłości. Tak więc

1 Por. Ewangelia w świecie. Orędzie Synodu Biskupów do ludu Bożego, „L'Osservatore Romano" 33 (2012) nr 12, s. 32-33; J. Sullivan, The beauty of holiness. Sacred art and the New Evangelization, Washington 2012, s. 9-13. 
trzeba, aby formacja w via pulchritudinis została włączona w przekazywanie wiary ${ }^{2}$.

Do formacji w via pulchritudinis przyczynia się niewątpliwie muzyka sakralna, która jest owocem twórczego dialogu pomiędzy sztuką muzyczną a wiarą chrześcijańską. Jej celem jest, jak podkreśla papież Franciszek, „wzbudzenie zachwytu i pragnienia piękna, pogłębianie wrażliwości duchowej i zamiłowania do wszystkiego, co jest autentycznym wyrazem ludzkiego geniuszu i odbiciem Bożego Piękna" ${ }^{\prime 2}$. Z tego dialogu zrodziły się na przestrzeni wieków niezliczone arcydzieła będące wyrazem misji kompozytorów chrześcijańskich - dawania świadectwa wiary poprzez tworzone piękno. To „piękne świadectwo” w głoszeniu Ewangelii zakłada „umiejętność odczytywania i zgłębiania piękna dzieł sztuki inspirowanych wiarą i tworzonych przez ludzi wierzących, aby odkryć w nich szczególną drogę, która

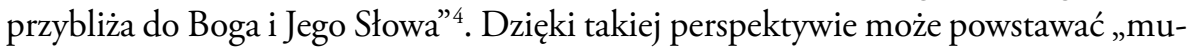
zyka na miarę świętości”, która ma moc prowadzenia nas „drogą piękna” ku Bogu.

\section{Kompozytor wobec scicrum}

W ostatnich latach wzrosło zainteresowanie terminem sacrum $\mathrm{w}$ odniesieniu do sztuki. Słowa sacrum nadużywa się jednak, nadając mu znaczenie będące często zaprzeczeniem samej idei świętości. We współczesnej kulturze określeniem sacrum próbuje się zastąpić samo pojęcie Boga. Termin ten stał się rodzajem „worka”, do którego wrzuca się różne, niejednokrotnie sprzeczne ze sobą treści. Dotyczy to także sztuki, w której zbyt łatwo absolutyzuje się wymiar estetyczny, nadając mu cechy sakralne. Utożsamianie „estetyczności” z „sakralnością” jest błędem i prowadzi do spłycenia obydwu dziedzin.

Współczesna „kultura, która uświadomiła sobie granice profanum, podejmuje [...] wysiłek dotarcia do sacrum" ". Nie zawsze jednak oznacza to powrót do religijnego obrazu świata, ale raczej do bliżej nieokreślonej „nowej duchowości”, która przybiera charakter nihilistyczny ${ }^{6}$. Ekspresja twórcza nie wykracza wów-

2 Franciszek, adhort. apost. Evangelii gaudium, s. 167.

3 Franciszek, adhort. apost. Evangelii gaudium, s. 167.

4 Franciszek, adhort. apost. Evangelii gaudium, s. 167; por. W. Osial, Wizja wspótczesnej katechezy $w$ nauczaniu papieża Franciszka, "Warszawskie Studia Teologiczne” 27 (2014) nr 1, s. 293-306.

5 D. Bell, Sprzeczności kulturowe kapitalizmu, tłum. S. Amsterdamski, Warszawa 1994, s. 29.

6 Por. J. Mariański, Sekularyzacja - desekularyzacja - nowa duchowość. Studium socjologiczne, Kraków 2013, s. 148-170. 
czas poza samą siebie, ale prowadzi ku ekstatycznej samowoli mającej charakter artystycznej utopii. Niejednokrotnie wykorzystuje się wówczas motywy religijne, nadając im znaczenie nie tylko dalekie od sfery sacrum, ale nawet bluźniercze. W takiej sztuce Bóg albo wcale się nie pojawia, albo zostaje zrównany z doświadczeniem natury, losem lub bliżej nieokreśloną duchowością w stylu New $\mathrm{Age}^{7}$. Święty Jan Paweł II przestrzega, że jest to nic innego, jak „odradzanie się starych poglądów gnostyckich”, w których „w imię głębokiego poznania Boga ostatecznie odrzuca się Jego Słowo, zastępując je tym, co jest wymysłem samego człowieka”" Myśl tę rozwija Benedykt XVI, stwierdzając: „W takim kontekście kulturowym istnieje niebezpieczeństwo duchowej atrofii i pustki serca, które niekiedy przejawiają się w zastępczych formach przynależności religijnej i nieokreślonym spirytualizmie" .

Można dzisiaj zaobserwować dążenie do nadawania pojęciu sacrum charakteru neutralnej i bezwyznaniowej religijności. Twórca, lękając się konfesyjnego „zaszeregowania”, zamiast poszukiwać w sztuce odniesienia do osobowego Boga, woli odwoływać się do bliżej nieokreślonych (a przez to wygodnych) „znaków transcendencji”. Niejednokrotnie, aby ukazać swą „oryginalność” i wyrazić „twórczy bunt", posuwa się nawet do celowego zniekształcania elementów sakralnych, dążąc do bluźnierczego ,antysacrum”. Jedną z metod twórczych i cechą wielu działań artystycznych stała się profanacja sacrum i sakralizacja profanum ${ }^{10}$. Odnosząc się do tego zjawiska, Leszek Kołakowski zauważa obecną we współczesnej kulturze skłonność do przypisywania sakralnego sensu wszystkiemu: „Zuniwersalizować sacrum to je unicestwić. Powiedzieć, że wszystko jest sakralne, to tyle, co powiedzieć, że nic nie jest sakralne, jako że obie te jakości - sacrum i profanum - zrozumiałe są tylko w przeciwstawieniu wzajemnym, i każdą z nich można uchwycić tylko w opozycji do drugiej" "11. Nawiązując do tego typu zagrożeń w obrębie muzyki sakralnej, św. Jan Paweł II przypomniał, że:

nie wszystko, co znajduje się poza świątynią (profanum), jest jednakowo zdatne do tego, by przekroczyć jej próg. [...] Jeśli nie występują

7 J. Bramorski, Sztuka sakralna wobec wyzwań sekularyzacji, „Studia Nauk Teologicznych PAN" 9 (2014), s. 189-207.

8 Jan Paweł II, Przekroczyć próg nadziei, Lublin 1994, s. 80-81.

9 Benedykt XVI, Sekularyzacja jest trudna próba dla Kościota. Przemówienie do uczestników zgromadzenia plenarnego Papieskiej Rady ds. Kultury (8.03.2008), L'Osservatore Romano" 29(2008) nr 4, s. 35-36.

10 Por. J. Bramorski, Muzyka wobec sacrum i profanum, w: Musica vocale. Sacrum i profanum w muzyce wokalnej - studium przypadku, red. R. Minkiewicz, Gdańsk 2014, s. 9-27.

11 L. Kołakowski, Cywilizacja na tawie oskarżonych, Warszawa 1990, s. 144. 
jednocześnie zmysł modlitwy, godności i piękna, muzyka - instrumentalna i wokalna - zamyka sobie drogę wstępu do sfery tego, co święte i religijne $Z$ drugiej zaś strony znaczenie kategorii „muzyka sakralna” uległo dzisiaj takiemu poszerzeniu, że obejmuje repertuar, który nie może stać się częścią kultu bez pogwałcenia ducha i norm liturgii ${ }^{12}$.

Chrześcijańskie doświadczenie sacrum znajduje swoje apogeum w wejściu Boga przez osobę Jezusa Chrystusa w ludzką historię i pozostanie w niej za pośrednictwem obecnego i działającego w Kościele Ducha Świętego. To dzięki odwiecznemu Tchnieniu (hebr. ruah) w świecie i w nas objawia się piękno, które przychodzi spoza świata i spoza nas. To piękno, jak zauważa Stanisław Grygiel, „łączy ze sobą dwa brzegi, brzeg ludzki i brzeg boski, przepływając pomiędzy nimi" ${ }^{13}$. W immanencji sztuki człowiek odkrywa transcendencję zbawczej rzeczywistości Boga żywego i prawdziwego. Otwarta dzięki muzyce sakralnej via pulchritudinis pozwala „dotknąć” ludzkiego serca pięknem i pociągnąć je ku dobru, wyrażając w ten sposób tajemnicę spotkania Boga i człowieka ${ }^{14}$. Kompozytor, który pragnie tworzyć „muzykę na miarę świętości”, powinien zatem pamiętać, że chrześcijaństwo nie jest „rozpłynięciem się" w nieokreślonym sacrum, ale konkretną i personalną relacją, w której ludzkie ,ja” staje wobec Boga. Uznanie osobowego Boga, otwarcie się na Niego, implikuje intensywne doświadczenie własnego „ja”, które dokonuje się w akcie wiary. Realizuje się to także w postawie twórczej, gdy kompozytor pragnie uczynić swoje dzieło miejscem teofanii, czyli spotkania z Bożą Obecnością, która objawia się poprzez piękno. Treść, jaką niesie język muzyki, nie jest jedynie wytworem umysłu twórcy, ale odnosi się w tajemniczy sposób do Źródła piękna, którym może być tylko Bóg. To piękno, płynąc przez człowieka stworzonego „na obraz i podobieństwo Boże” (por. Rdz 1, 27), przemienia go i uzdalnia do tworzenia dzieł sztuki ${ }^{15}$. Aby to zrealizować, koniecznym warunkiem jest połączenie czterech czynników: wiary, powołania, natchnienia i łaski. To one poprzez pracę twórcy wpływają na jakość dzieła. Tworzenie to dar łaski, na którą artysta odpowiada pokorą. Wówczas sacrum może uobecnić się w substancji muzycznej. Najdobitniej ukazuje to chorał gregoriański, który w swych

\footnotetext{
12 Jan Paweł II, Mosso dal vivo desiderio, „Ethos” 19 (2006) nr 1-2, s. 15; por. P. A. Kwasniewski, John Paul II on Sacred Music, „Sacred Music” 133 (2006) nr 2, s. 4-22.

13 S. Grygiel, Na ścieżkach prawdy. Rozmawiając z Janem Pawtem II, Poznań 2013, s. 85.

14 Por. T. Bratkowski, Musica sacra w liturgii, „Studia Loviciensia” 13 (2010), s. 57-58.

15 Por. S. Grygiel, Na ścieżkach prawdy..., dz. cyt., s. 90-91; T. Boruta, Dzieto sztuki kościelnej-między znakiem a symbolem, „Znak” 43 (1991) nr 12, s. 66-69.
} 
konstrukcjach melodycznych zawiera rdzeń symboliki teologicznej ${ }^{16}$. W ten sposób, jak podkreśla św. Jan Paweł II, ten sięgający wczesnego średniowiecza śpiew „przenosi ludzkie dusze ze świata zmysłowego w rzeczywistość wieczną” ${ }^{17}$. Gdy słuchamy np. gregoriańskiej Missa de angelis, dzieł Palestriny czy Mszy h-moll Jana Sebastiana Bacha, trudno oprzeć się przekonaniu, że ich początkiem stała się nie tylko pobożność twórców, lecz także szczególne doświadczenie sacrum. W tych dziełach sztuki zdolni jesteśmy usłyszeć sacrum, które odnosi nas do religijnych przeżyć kompozytorów ${ }^{18}$.

Osobiste doświadczenie religijne kompozytora nie może być jednak pojmowane indywidualistycznie, w oderwaniu do zasad liturgii i sensus Ecclesiae. Nurt postmodernizmu stał się pretekstem do tego, aby sprowadzić sztukę do wyrazu indywidualistycznego, mającego siebie za punkt odniesienia, oraz badać wszelkie możliwe odejścia od kanonów tradycyjnych, dla których osiągnięcie piękna było gwarancją zaistniałej komunikacji między dziełem a jego odbiorcą ${ }^{19}$. Tendencja do „antyinstytucjonalnego” traktowania religii znajduje swoje odzwierciedlenie także w twórczości muzycznej. Mamy wówczas do czynienia ze swoistą ,idolatrią twórczą" (od gr. eidolon - obraz lub posąg, latreia - kult), polegającą na ubóstwieniu przez kompozytora swojego dzieła. Przestrzegał przed tym artystów biskup Karol Wojtyła:

Bóg Ewangelii jest artyście potrzebny nie tylko jako źródło natchnień - twórczych, artystycznych. Ten Bóg Ewangelii jest o wiele bardziej jeszcze potrzebny artyście jako człowiekowi. Jest potrzebny każdemu z nas - ten Bóg, który jest Pięknem. To Piękno, które jest Bogiem, jest potrzebne każdemu z nas, ażebyśmy nie zatrzymali się ostatecznie tylko przy tym pięknie, które sami tworzymy. Żeby nasze własne dzieła nie wyrosły dla nas do rzędu bożyszcz. Żebyśmy ich nie ubóstwili. To jest wielka pokusa, zdawać by się mogło wzniosła pokusa, pokusa artysty: ubóstwić swoje własne dzieła. W nich widzieć namiastkę Boga, bożyszcze. Wtedy mówi się, ze sztuka przesłania mi Boga. Ubóstwiając swoje własne dzieła, [...] jakoś człowiek ubóstwia siebie. To jest wielka, tragiczna pokusa. Pokusa tym większa i tym

\footnotetext{
16 Por. P. Wiśniewski, Duchowość choratu gregoriańskiego, „Liturgia Sacra” 19 (2013) nr 1, s. 103-118; W. Mahrt, Gregorian chant as a paradigm of sacred music, "Sacred Music" 133 (2006) nr 1, s. 5-14.

17 Jan Paweł II, List do artystów, 7.

18 Por. K. Kiwała, Muzyka i świętość. Rekonesans, „Ethos” 27 (2014) nr 1, s. 195-213; J. A. Piquet, L'orecchio pensante. Ascoltare il nome trinitario di Dio. Dal Gregoriano a W. A. Mozart e Ch. Gounod, w: La liturgia alla prova del sacro, a cura di P. Tomatis, Roma 2013, s. 245-276.

19 Por. P. Portoghesi, Sztuka i nowa ewangelizacja, „L'Osservatore Romano” 33 (2012) nr 3, s. $46-48$.
} 
tragiczniejsza, im mniej sobie człowiek, artysta, człowiek sztuki zdaje z niej sprawę - z tego, że ona jest i czym ona jest. Bo człowiek siebie nie może ubóstwićn ${ }^{20}$.

Piękno sztuki to jeszcze nie sacrum, ale droga do niego. Dzieło tylko wtedy jest prawdziwe, gdy wskazuje na rzeczywistość większą od siebie, gdy ją odsłania i do niej prowadzi. To nie sztuka jest święta - ona jedynie pozwala nam w krótkim przebłysku dostrzec i doświadczyć świętości. Poszukiwanie poprzez sztukę ostatecznego fundamentu rzeczywistości jest otwarciem się na to, co Nieznane i co pozwala się raczej „przeczuć”, niż „poznać”. U kresu poznania jest Niepoznawalne, a u kresu rozumienia - Niezrozumiałe. Muzyka sakralna jest otwarciem się na głębię i tajemnicę istnienia, sposobem poznania, w którym do człowieka docierają przebłyski Nieogarnionego ${ }^{21}$. Dlatego kompozytorzy nie mogą ograniczać się do postawy estetyzmu, kontemplując jedynie piękno samego dzieła. Prawdziwie wielka sztuka jest jak światło wskazujące drogę wzwyż. Sugestywnie wyraził to Zbigniew Herbert w słynnym Przestaniu Pana Cogito: „Czuwaj - kiedy światło w górach daje znak - wstań i idź. [...] Bądź wierny idź”22.

\section{Muzyka sakralna nośnikiem piękna wiary}

Sposobem odkrycia owego „światła w górach” jest muzyka sakralna, będąca szczególnie sugestywnym ,językiem przypowieści” w przekazywaniu wiary. To przez nią kompozytor zbliża się do Boga, odkrywając w Nim źródło życia, miłości, prawdy, piękna oraz inspiracji twórczej. Rola muzyki sakralnej nie ogranicza się jedynie do wymiaru estetycznego, ale jest przede wszystkim działalnością ewangelizacyjną ${ }^{23}$. Odpowiedzią Kościoła na współczesne procesy sekularyzacyjne jest program nowej ewangelizacji, w której istotną rolę pełni twórczość artystyczna. Dzieła sztuki przez właściwą sobie specyfikę dają możliwość przybliżenia człowiekowi prawd chrześcijańskiej wiary. Pomimo przemian kulturowych sztuka, w swej najgłębszej istocie, zachowuje więź wewnętrznego pokrewieństwa ze światem wiary, stając się w każdym czasie swego rodzaju pomostem, prowadzącym do doświadczenia re-

\footnotetext{
20 K. Wojtyła, Ewangelia a sztuka, Kraków-Rzym 2011, s. 33-34; por. S. Grygiel, Na ścieżkach prawdy..., dz. cyt., s. 102-106.

21 Por. K. Tarnowski, Muzyka, filozofia, transcendencja, „Znak” 43 (1991) nr 12, s. 98-101.

22 Z. Herbert, Przestanie Pana Cogito, „Nowa Polszczyzna” 5 (1998), s. 35.

23 Por. J. Bramorski, Muzyka sakralna jako epifania piękna w świetle myśli św. Jana Pawta II, w: Muzyka sakralna wobec wspótczesnych wyzwań kulturowych, red. J. Bramowski, Gdańsk 2014, s. 11-31; M. Lieggi, C. Alfano, Vangelo e bellezza. Evangelizzare attraverso l'arte e la musica, „L'Odegitria” 86 (2010) nr 2, s. 255-263.
} 
ligijnego ${ }^{24}$. Bardzo mocno akcentował to św. Jan Paweł II, dostrzegając pilną potrzebę przekazywania ewangelicznego orędzia na gruncie kultury ${ }^{25}$.

Nowa ewangelizacja potrzebuje sztuki, ale takiej, która potrafi odróżnić piękno prawdziwe od piękna złudnego. Podejmując refleksję nad tym zagadnieniem, Benedykt XVI zauważa:

Zbyt często jednak piękno, które bywa reklamowane, jest złudne i kłamliwe, powierzchowne, zaślepiające i odurzające, i zamiast skłaniać ludzi do przekraczania siebie, wskazywać im horyzonty prawdziwej wolności, pociągając ku temu, co w górze, więzi ich w samych sobie i jeszcze bardziej zniewala, pozbawia nadziei i radości. Jest to piękno fascynujące, lecz obłudne, które rozbudza żądzę, pragnienie władzy, posiadania, dominacji nad drugim [...] popada w obsceniczność, transgresję bądź bezcelową prowokację. Natomiast prawdziwe piękno rodzi w ludzkim sercu tęsknotę, głębokie pragnienie poznania, kochania, zbliżenia się do Drugiego, do tego, co je przerasta ${ }^{26}$.

Pilnym zadaniem artystów, teologów i duszpasterzy staje się w związku z tym odróżnienie „autentycznego piękna”, które pociąga nas ku temu, co w górze, od „piękna złudnego”, które nas zniewala. Pierwsze ma istotne znaczenie w programie nowej ewangelizacji, drugie jest jego przeciwieństwem, gdyż sprzyja umacnianiu się sekularyzacji, nihilizmu i usuwania pierwiastka nadprzyrodzonego z życia społecznego.

Muzyka sakralna będąca nośnikiem „autentycznego piękna” stawia swoim twórcom wysokie wymagania. Niestety artyści zbyt często przejmują obecnie wzorce kultury popularnej. Przykładem tego są melodie rozbrzmiewające w kościołach, których estetyka bliższa jest niekiedy dyskotece niż świątyni ${ }^{27}$. Sekularyzacja sztuki sakralnej powoduje banalizację sacrum. Przyczyną tego jest mylne przekonanie niektórych twórców i duszpasterzy, że kryterium sztuki jako narzędzia ewangelizacji powinno być dostosowanie jej do przeciętnych gustów. W ten sposób język

24 Por. M. Carbajo Núnez, La gioia di evangelizzare: potenzialità della via pulchritudinis e del linguaggio narrativo, „Antonianum” 89 (2014) nr 4, s. 571-609; S. Szupieńko, Piękno i sztuka-ewangelizacja i Kościót, „Anamnesis” 73 (2013) nr 6, s. 114.

25 Jan Paweł II, Powotanie do życia Papieskiej Rady do Spraw Kultury. List do Kardynata Sekretarza Stanu, „L'Osservatore Romano” 3(1982) nr 5, s. 26-27.

26 Benedykt XVI, Bądźcie zwiastunami i świadkami nadziei (21.11. 2009), „L'Osservatore Romano" 31 (2010) nr 2, s. 31.

27 Por. J. Waloszek, Drogi i bezdroża muzyki kościelnej w Polsce po Soborze Watykańskim II, „Liturgia Sacra” 19 (2013) nr 2, s. 397-405. 
popkultury przenika do twórczości religijnej. Zwłaszcza przenoszenie „produktów kultury masowej” do liturgii winno budzić zdecydowany sprzeciw. Są one bowiem nie tylko niezgodne z autentycznym duchem liturgii, ale niejednokrotnie desakralizują miejsce jej sprawowania i nie służą duchowemu dobru wiernych ${ }^{28}$.

Muzyka sakralna należy do obszaru sztuki wysokiej. Jeśli ma ona stać się „nośnikiem piękna" i skutecznym narzędziem ewangelizacji, nie należy ograniczać jej tylko do wąskiego kręgu koneserów, ale uczynić zrozumiałą dla ogółu współczesnych odbiorców. Czy jednak jest w ogóle możliwa taka sztuka, która odznacza się wysokim poziomem, a jednocześnie przemawia do wielu? Odpowiadając na to pytanie, Witold Gombrowicz trafnie zauważył, że „cud kultury chrześcijańskiej polega na tym, że jest ona wielka dla wielu" ${ }^{29}$. Dzięki temu via pulchritudinis, obecna w muzyce sakralnej, może stać się współczesnym „areopagiem” głoszenia Chrystusowej Dobrej Nowiny.

\section{Kompozytor jako świadek piękna wiary}

W 2006 r. Papieska Rada ds. Kultury, wychodząc od prostego doświadczenia piękna, zwróciła uwagę na to, że sztuka sakralna wzbudza w człowieku uczucie podziwu, otwierając przed nim drogę do poszukiwania ostatecznego źródła piękna, jakim jest Bóg. Jednocześnie osoba ludzka zostaje pociągnięta ku dobru, którego „widzialnością” jest niejako piękno. Pulchrum łączy się ściśle z bonum, które stanowi jego metafizyczny warunek. Piękno nie może zostać zredukowane jedynie do rangi przyjemności zmysłowej, gdyż jego natura jest uniwersalna i jako transcendentale, czyli wartość najwyższa, prowadzi do odkrycia odwiecznej prawdy i pełni Bytu. Muzyka sakralna tylko wówczas odnajduje swój sens, gdy nie zatrzymuje się na estetycznym wymiarze piękna, ale odnosi się do transcendencji. W ten sposób umożliwia ona spotkanie świata ducha i materii ${ }^{30}$.

Piękno, jako droga chrześcijańskiego świadectwa wiary, stanowi ,jedną z możliwych dróg, być może najbardziej pociągającą i fascynująca, aby zrozumieć Boga i dotrzeć do Niego"31. Benedykt XVI podkreśla, że piękno prowadzi do spotkania Boga: „Via pulchritudinis - droga piękna - jest uprzywilejowaną i fascynują-

28 Por. A. Zając, Inkulturacja w obszarze muzyki liturgicznej wobec wyzwań wspótczesnej muzycznej pop-kultury, w: Musicam Sacram Promovere, red. R. Tyrała, Kraków 2004, s. 65-78.

29 Cyt. za: M. Dobrzyniak, P. Radzyński, Sacrum profokowane-mysterion vs. Happening. Koegzystencja religii i kultury masowej, „Colloquia Theologica Ottoniana” 1 (2012), s. 196.

30 Por. Pontificio Consiglio della Cultura, La via pulchritudinis, cammino privilegiato di evangelizzazione e di dialogo, Roma 2006, II, 3; A. F. Dziuba, Sztuka-spotkanie świata ducha i materii, „Studia Loviciensia” 13 (2010) , s. 105-106.

31 Benedykt XVI, Bądźcie zwiastunami i świadkami nadziei, dz. cyt., s. 31. 
cą drogą zbliżenia się do tajemnicy Boga. Czym jest piękno, które pisarze, poeci, muzycy, artyści rozważają i przekładają na swój język, jeśli nie odbiciem blasku Słowa wiecznego, które stało się ciałem?”32. Via pulchritudinis łączy w sobie wymiar artystyczno-estetyczny z wymiarem teologicznym. Benedykt XVI zwraca się z zachętą: „Niech Pan pomoże nam odkryć na nowo drogę piękna jako jedną z dróg, być może najbardziej pociągającą i fascynującą, by dotrzeć do Boga, spotkać Go i miłować”33.

Znaczenie piękna w liturgicznym aspekcie życia chrześcijańskiego zaakcentował papież Benedykt XVI w adhortacji Sacramentum caritatis:

Związek pomiędzy tajemnicą, w którą się wierzy, i tajemnicą, którą się celebruje, wyraża się w sposób szczególny w teologicznej i liturgicznej wartości piękna. [...] Odnoszenie się do atrybutu piękna nie jest jedynie estetyzmem, ale jest sposobem docierania do nas prawdy o miłości Boga w Chrystusie poprzez piękno. Fascynuje nas i porywa, odrywając nas od nas samych i pociągając nas ku naszemu prawdziwemu powołaniu: ku miłości. [...] Piękno nie jest więc jedynie czynnikiem dekoracyjnym liturgii; ono jest jej elementem konstytutywnym, gdyż jest atrybutem samego Boga i Jego Objawienia. Wszystko to winno sprawić, byśmy byli świadomi, jaką należy zachować uwagę, by liturgia jaśniała zgodnie z jej właściwą naturą ${ }^{34}$.

Docenienie znaczenia via pulchritudinis w teologii i w muzyce sakralnej łączy się jednocześnie ze świadomością, że nie jest ona drogą autonomiczną, ale powinna być odczytywana w Duchu Świętym działającym w Kościele i przez Kościół. Via pulchritudinis rodzi się na gruncie przekazu biblijnego, którego narzędziem jest kerygmat. Odczytanie zaś zawartej w Piśmie Świętym treści Objawienia wyraża się w dogmatach wiary. Dlatego pogłębiona znajomość Biblii oraz nauczania Kościoła stanowi nieodzowny element odczytywania prawdziwego sensu muzyki sakralnej oraz tworzenia jej w zmieniającym się kontekście historyczno-kulturowym. Myśliciele średniowieczni byli przekonani, że „sztuka bez wiedzy nic nie jest warta”. Dlatego podejmowanie przez kompozytorów refleksji teologicznej pomoże im wy-

32 Benedykt XVI, O znaczeniu piękna jako drogi spotkania Boga (18.11.2009), „Wiadomości KAI” 48 (2009), s. 23-24; por. B. Forte, La „via pulchritudinis" un "ponte” tra fede e culture, w: La via della bellezza. Cammino di evangelizzazione e dialogo, a cura di G. Mura, Città del Vaticano 2006, s. 65-69.

33 Benedykt XVI, O znaczeniu piękna jako drogi spotkania Boga, dz. cyt., s. 24.

34 Benedykt XVI, adhort. apost. Sacramentum caritatis, s. 35. 
raźniej dostrzec bogactwo treści duchowych, które mogą być wyrażone poprzez tworzone przez nich dzieła ${ }^{35}$.

W tej perspektywie zarysować można podstawowe elementy etosu kompozytora muzyki sakralnej, pojmującego swoją pracę nie tylko jako zawód, ale przede wszystkim jako powołanie. Aby kompozytor mógł we właściwy sposób przeżywać swą artystyczną i osobową tożsamość, ważne jest przyjęcie przez niego zarówno postawy kontemplacji wobec piękna wiary, jak i gotowości do dawania świadectwa. Zwrócił na to uwagę Benedykt XVI, nazywając artystów „świadkami piękna wiary" (pulchritudinis fidei testis) i wzywając ich, aby uczestniczyli w misji Kościoła, szczególnie wtedy, gdy tworzą „dzieła sztuki bezpośrednio związane z czynnościami liturgicznymi Kościoła”36. Komponowanie muzyki sakralnej zgodnie z wymaganiami liturgii stanowi formę apostolatu i służy budowaniu wspólnoty wierzących. Dlatego praca kompozytora jest służbą liturgiczną i pastoralną. Jednocześnie jest także profesją artystyczną, wymagającą zarówno rzetelnych kwalifikacji muzycznych, jak i teologicznych ${ }^{37}$. Kardynał Joseph Ratzinger podkreśla: „Ponieważ posługa muzyczna jest posługą liturgiczną, można ją z pewnością pełnić jako formę posługi duszpasterskiej, a także kapłańskiej. Muzyka kościelna, która w swym wykonaniu rzeczywiście odpowiada wymogom liturgii, jest rodzajem apostolatu i służy budowaniu wspólnoty" ${ }^{38}$.

Stanisław Grygiel formułuje najgłębsze kryterium piękna sztuki sakralnej, które jednocześnie jest wezwaniem dla jej twórców:

Piękno bowiem nie jest z ziemi, mimo że na niej się wydarza. Wydarza się tylko w człowieku zachwyconym do nieba. Stamtąd widzi on siebie i świat tak, jak widzi ich stwórcze Spojrzenie, theos, zapalające ich do istnienia. Człowiek zachwycony w niebo łączy się z tym Spojrzeniem i dzięki Niemu twórczo patrzy na siebie oraz na wszystko dookoła. W swoim wnętrzu tworzy dzieło sztuki, które uwydatnia piękno jego osoby, a w niej piękno

35 Por. P. Casarella, „A healthy shock”. Tradition and the epiphany of beauty, w: Tradition as the future of innovation, ed. E. Grimi, Newcastle upon Tyne 2015, s. 220-241; J. Królikowski, Nieme stowo. Teologia w sztuce, Tarnów 2008, s. 81-84.

36 Benedykt XVI, Świadkowie piękna wiary. Przestanie do uczestników XVII sesji publicznej Akademii Papieskich (21.11. 2012), „L'Osservatore Romano” 34 (2013) nr 1, s. 31.

37 Por. R. Pośpiech, Edukacja i formacja liturgiczno-muzyczna, w: Musicam Sacram Promovere, dz. cyt., s. 47-64.

38 J. Ratzinger, Teologia liturgii. Sakramentalne podstawy życia chrześcijańskiego, tłum. W. Szymona, Lublin 2012, s. 570. 
ziemi. Tak dopełniając pracę Boga, na co czeka całe stworzenie, objawia się jako syn Boży (por. Rz 8, 19-21) ${ }^{39}$.

Piękno ukazuje się tym, którzy je kontemplują. Kompozytor, trwając w kontemplacyjnym zasłuchaniu, „przekracza siebie i wyrasta ponad siebie” w postawie autotranscendencji. Fascynacji ponadczasowym pięknem, które odkrywa, towarzyszy pokora wynikająca z poczucia, że w wymiarze doczesnym nigdy nie będzie mu dane absolutne spełnienie. Dlatego Benedykt XVI podkreśla: „Musimy być pokorni i nie pokładać ufności w nas samych, lecz pracować z Bożą pomocą”º Pochylając się nad tajemnicą Absolutu, która wyłania się spoza harmonii dźwięków, kompozytor może powtórzyć wyznanie biblijnego Hioba: „Jam mały, cóż Ci odpowiem? Rękę przyłożę do ust” (Hi 40, 4). Przed misterium Boga pozostaje artyście zamilknąć - nie wszystko bowiem da się wypowiedzieć do końca, nawet w języku sztuki ${ }^{41}$. Kapłan-poeta Jan Twardowski określił to w następujący sposób:

Bóg jako największy artysta nie dopowiedział pewnych rzeczy do końca. Dzięki temu istnieje niesłychany urok życia: jest miejsce na niepoznane, na niewidzialne. Wszelka próba usuwania tych niedomówień jest zubożaniem życia. Artysta nie może dopowiadać tak jak Bóg, który nie dopowiedział do końca wielu rzeczy. [...] Wielka sztuka zawsze stawia człowieka przed czymś niedokończonym. Prawdziwy artysta nigdy niczego do końca nie dopowiada, bo przestałby być artystą. Muszą to zrobić uczestnicy jego dzieła. Poeta musi opisywać to, czego nie widzi. Myślę, że to, co ukrywa się w tajemnicy, to jest źródło poezji. Poeta widzi świat ukryty, niewidzialny, inny. Artysta coś przenosi z tamtej rzeczywistości w tę ${ }^{42}$.

Słowa te odnoszą się również do kompozytorów, którzy chociaż dotykają swą sztuką Nieskończoności, nie są jednak zdolni do końca poznać, zrozumieć i wyrazić jej piękna oraz doskonałości. Witold Broniewski trafnie zauważa: „Sztuka nie może w pełni przełożyć Niewidzialnego na widzialne. Stąd musi zadowolić się aluzją i zaznaczeniem. Udaje się jej jedynie muśnięcie Niewyrażalnego. Kończy się niedopowiedzeniem [...]. U kresu kontemplacji [...] jest niemoc mówienia zwana

\footnotetext{
39 S. Grygiel, Na ścieżkach prawdy..., dz. cyt., s. 104.

40 Benedykt XVI, Modlitwa kontemplacyjna doświadczeniem Boga i naszej stabości (13.06.2012), „Wiadomości KAI” 25 (2012), s. 19.

41 Por. J. Bramorski, Pieśń nowa cztowieka nowego, Gdańsk 2012, s. 442-452.

42 J. Twardowski, O artystach i poezji, w: Jan Pawet II do artystów. Artyści do Jana Pawta II, Lublin 2006, s. 704.
} 
milczeniem i niemy zachwyt dla Niewyrażalnego" ${ }^{43}$. W ten sposób kontemplacja staje się adoracją. Muzyka, która otwiera nas na kontemplację Bożego Piękna, ma w sobie coś anielskiego. Dlatego kard. Joseph Ratzinger zauważa: „Istotą życia aniołów jest adoracja. Przyjąć formę życia aniołów znaczy uczynić ze swego życia adorację - w takim stopniu, w jakim pozwala na to ludzka słabość” ${ }^{44}$. W tej pespektywie kompozytor jako świadek niewyrażalnego piękna samego Boga jest wezwany, aby „wobec aniołów psalm zaśpiewać Panu” (por. Ps 138, 1).

\section{Streszczenie}

\section{Muzyka sakralna jako via pulchritudinis wyzwaniem dla kompozytorów}

Jeśli natura i kosmos są odblaskiem piękna Stwórcy i prowadzą nas do kontemplacji Jego wielkości, to również twórczość artystyczna ma możliwość przybliżania nas do tajemnicy Boga. Dla człowieka wierzącego piękno wykracza poza estetykę i odnajduje swój archetyp w Bogu. Kontemplacja odwiecznej piękności jest źródłem, z którego kompozytorzy chrześcijańscy czerpią natchnienie, aby ukazywać w swej twórczości misterium Boga. Inspirowane wiarą chrześcijańską dzieła muzyki sakralnej pozwalają nam w intuicyjny sposób uczestniczyć w doświadczeniu wiary, odkrywając tajemnicę miłości Boga i tożsamości człowieka. Posługując się językiem piękna, dzieła muzyczne są nie tylko nośnikami przesłania artysty, ale także prawdy o Bogu. Kompozytor, ukazując ową prawdę, nie wychwala samego siebie, ale pragnie uwielbiać Źródło Piękna. W liturgii, będącej istotnym momentem w doświadczaniu dojrzałej wiary, piękna nie można zredukować jedynie do formalnego estetyzmu. Jest to przede wszystkim głębokie piękno spotkania z tajemnicą Boga. Dlatego w muzyce liturgicznej nie ma miejsca na powierzchowność, banalność i niedbałość. Muzyka nie pomagałaby wówczas w rozwoju wiary, ale wręcz stawałaby się przeszkodą w godnym uczestniczeniu w chrześcijańskich obrzędach. Piękno stanowi zatem jedną z fundamentalnych kategorii teologicznych, pomagając wzrastać w wierze oraz dążyć do prawdy. Istotną rolę ewangelizacyjną pełni w tym kontekście muzyka sakralna, która jako via pulchritudinis stanowi wspaniały wyraz wiary, nadziei i miłości.

43 W. Broniewski, O kontemplacji (2), „Kwartalnik Artystyczny” 11 (2003) nr 4, s. 113.

44 J. Ratzinger, Nowa pieśń dla Pana, tłum. J. Zychowicz, Kraków 1999, s. 202-203. 


\section{Summary}

\section{Sacred music as via pulchritudinis - a challenge to composers}

If nature and cosmos are the expression of the beauty of the Creator and bring us to the threshold of a contemplative silence, artistic creation possesses its own capacity to evoke the ineffable aspects of the mystery of God. For the believer, beauty transcends the aesthetics and finds its archetype in God. The contemplation of the eternal beauty is the living source from which the Christian composers take inspiration to speak of the mystery of God. Works of sacred music inspired by the Christian faith posses an enormous potential pertinent to contemporary needs that remain unaltered by the times that pass. In an intuitive and tasteful manner, they permit participation in the great experience of faith, the meeting with God in the face of Christ in whom he uncovers the mystery of the love of God and the identity of man. With the language of beauty, Christian musicwork does not only transmit the message of the artist, but also the truth of the mystery of God meditated by a person who reads it to us, not to glorify himself but to glorify the Source. The beauty of the liturgy, an essential moment in the experience of faith and the pathway towards the adult faith, is unable to reduce itself to mere formal beauty. It is, first of all, the deep beauty of the meeting with the mystery of God. Superficiality, banality and negligence have no place in the liturgical music. They definitely do not help the believers progress on his path of faith but, above all, damage those who attend Christian celebrations. Beauty is seen as fundamental to faith and to the perception of truth. Via pulchritudinis as the way of beauty in sacred music is the finest expression of faith, hope and love.

Stowa kluczowe: via pulchritudinis, muzyka sakralna, droga piękna, nowa ewangelizacja

Keywords: via pulchritudinis, sacred music, the way of beauty, new evangelization

\section{Bibliografia}

Bell D., Sprzeczności kulturowe kapitalizmu, tłum. S. Amsterdamski, Warszawa 1994.

Benedykt XVI, Bądźcie zwiastunami i świadkami nadziei (21.11. 2009), „L'Osservatore Romano" 31 (2010) nr 2, s. 31.

Benedykt XVI, Modlitwa kontemplacyjna doświadczeniem Boga $i$ naszej stabości (13.06.2012), „Wiadomości KAI” 25 (2012), s. 19.

Benedykt XVI, O znaczeniu piękna jako drogi spotkania Boga (18.11.2009), „Wiadomości KAI" 48 (2009), s. 23-24.

Benedykt XVI, Sacramentum caritatis, Città del Vaticano 2007. 
Benedykt XVI, Sekularyzacja jest trudna próba dla Kościota. Przemówienie do uczestników zgromadzenia plenarnego Papieskiej Rady ds. Kultury (8.03.2008), „L'Osservatore Romano" 29 (2008) nr 4, s. 35-36.

Benedykt XVI, Świadkowie piękna wiary. Przestanie do uczestników XVII sesji publicznej Akademii Papieskich (21.11. 2012), „L'Osservatore Romano” 34 (2013) nr 1, s. 31.

Boruta T., Dzieto sztuki kościelnej - między znakiem a symbolem, „Znak” 43 (1991) nr 12, s. 66-69.

Bramorski J., Pieśń nowa cztowieka nowego, Gdańsk 2012.

Bramorski J., Muzyka sakralna jako epifania piękna w świetle myśli św. Jana Pawta II, w: Muzyka sakralna wobec wspótczesnych wyzwań kulturowych, red. J. Bramorski, Gdańsk 2014, s. 11-31.

Bramorski J., Muzyka wobec sacrum i profanum, w: Musica vocale. Sacrum i profanum w muzyce wokalnej-studium przypadku, red. R. Minkiewicz, Gdańsk 2014, s. 9-27.

Bramorski J., Sztuka sakralna wobec wyzwań sekularyzacji, „Studia Nauk Teologicznych PAN” 9 (2014), s. 189-207.

Bratkowski T., Musica sacra w liturgii, „Studia Loviciensia” 13 (2010), s. 57-68.

Broniewski W., O kontemplacji (2), „Kwartalnik Artystyczny” 11 (2003) nr 4, s. 109-114.

Carbajo Núñez M., La gioia di evangelizzare. Potenzialità della via pulchritudinis e del linguaggio narrativo, „Antonianum” 89 (2014) nr 4, s. 571-609.

Casarella P., "A healthy shock”. Tradition and the epiphany of beauty, w: Tradition as the future of innovation, ed. E. Grimi, Newcastle upon Tyne 2015, s. 220-241.

Dobrzyniak M., Radzyński P., Sacrum profokowane - mysterion vs. Happening. Koegzystencja religii i kultury masowej, „Colloquia Theologica Ottoniana” 1 (2012), s. 189-206.

Dziuba A. F., Sztuka - spotkanie świata ducha i materii, „Studia Loviciensia” 13 (2010), s. $107-115$.

Ewangelia w świecie. Orędzie Synodu Biskupów do ludu Bożego, „L'Osservatore Romano” 33 (2012) nr 12, s. 32-33.

Forte B., La "via pulchritudinis" un "ponte" tra fede e culture, w: La via della bellezza. Cammino di evangelizzazione e dialogo, a cura di G. Mura, Città del Vaticano 2006, s. 65-69.

Franciszek, Evangelii gaudium, Città del Vaticano 2013.

Grygiel S., Na ścieżkach prawdy. Rozmawiając z Janem Pawtem II, Poznań 2013.

Herbert Z., Przestanie Pana Cogito, „Nowa Polszczyzna” 5 (1998), s. 35.

Jan Paweł II, List do artystów, „L'Osservatore Romano” 20 (1999) nr 5-6, s. 4-11.

Jan Paweł II, Mosso dal vivo desiderio, „Ethos” 19 (2006) nr 1-2, s. 15-21.

Jan Paweł II, Powotanie do życia Papieskiej Rady do Spraw Kultury. List do Kardynata Sekretarza Stanu, „L'Osservatore Romano” 3 (1982) nr 5, s. 26-27.

Jan Paweł II, Przekroczyć próg nadziei, Lublin 1994.

Kiwała K., Muzyka i świętość. Rekonesans, „Ethos” 27 (2014) nr 1, s. 195-213. 
Kołakowski L., Cywilizacja na tawie oskarżonych, Warszawa 1990.

Królikowski J., Nieme stowo. Teologia w sztuce, Tarnów 2008.

Kwasniewski P. A., John Paul II on Sacred Music, „Sacred Music” 133 (2006) nr 2, s. 4-22.

Lieggi M., Alfano C., Vangelo e bellezza: evangelizzare attraverso l'arte e la musica, „L'Odegitria" 86 (2010) nr 2, s. 255-263.

Mahrt W., Gregorian chant as a paradigm of sacred music, „Sacred Music” 133 (2006) nr 1, s. 5-14.

Mariański J., Sekularyzacja - desekularyzacja - nowa duchowość. Studium socjologiczne, Kraków 2013.

Osial W., Wizja wspótczesnej katechezy w nauczaniu papieża Franciszka, „Warszawskie Studia Teologiczne" 27 (2014) nr 1, s. 293-306.

Piquet J. A., L'orecchio pensante. Ascoltare il nome trinitario di Dio. Dal Gregoriano a W. A. Mozart e Ch. Gounod, w: La liturgia alla prova del sacro, a cura di P. Tomatis, Roma 2013, s. 245-276.

Pontificio Consiglio della Cultura, La via pulchritudinis, cammino privilegiato di evangelizzazione e di dialogo, Roma 2006.

Portoghesi P., Sztuka i nowa ewangelizacja, „L'Osservatore Romano” 33 (2012) nr 3, s. 46-48.

Pośpiech R., Edukacja i formacja liturgiczno-muzyczna, w: Musicam Sacram Promovere, red. R. Tyrała, Kraków 2004, s. 47-64.

Ratzinger J., Nowa pieśń dla Pana, tłum. J. Zychowicz, Kraków 1999.

Ratzinger J., Teologia liturgii. Sakramentalne podstawy życia chrześcijańskiego, tłum. W. Szymona, Lublin 2012.

Sullivan J., The beauty of holiness. Sacred art and the New Evangelization, Washington 2012.

Szupieńko S., Piękno i sztuka - ewangelizacja i Kościót, „Anamnesis” 73 (2013) nr 6, s. 113-119.

Tarnowski K., Muzyka, filozofia, transcendencja, „Znak” 43 (1991) nr 12, s. 98-101.

Twardowski J., O artystach i poezji, w: Jan Pawet II do artystów. Artyści do Jana Pawta II, Lublin 2006, s. 702-712.

Waloszek J., Drogi i bezdroża muzyki kościelnej w Polsce po Soborze Watykańskim II, „Liturgia Sacra” 19 (2013) nr 2, s. 397-405.

Wiśniewski P., Duchowość choratu gregoriańskiego, „Liturgia Sacra” 19 (2013) nr 1, s. $103-118$.

Wojtyła K., Ewangelia a sztuka, Kraków-Rzym 2011.

Zając A., Inkulturacja w obszarze muzyki liturgicznej wobec wyzwań wspótczesnej muzycznej pop-kultury, w: Musicam Sacram Promovere, red. R. Tyrała, Kraków 2004, s. 65-78. 